\title{
GROVITH PERFORMANCE OF LARGE DIAMETER RATTAN (Calamus) PLANTED UNDER PINE PLANTATIONS AT SINHARAJA BUFFERZONE.
}

\author{
H. S. Gammanpila1' B.M.P. Singhakumarạ1 \& P.M.S. Ashton² \\ 1 Department of Forestry and Environmental Science, \\ University of Sri Jayawardenepura \\ ${ }^{2}$ School of Forestry and Environmental Studies, Yalo University, USA.
}

Rattans can be considered as the most important non-timber forest product. Due to heavy exploitation from the wild, the resource is declining at an alarming rate. The present study examined the growth performance in terms of plant height, total lengths of stems, diameter, clump formation and number of live leaves and average growth rates of three large diameter rattan species, namely Ca'aimus zeylanicus Becc., Calamus thwaitesii Becc., and Calamus ovoideus Thw. ex Trim, planted under pine plantations in the buffer zone of Sinharaja, Sri Lanka. Four sites of rattan plantations in ages, 8, 9, 10 and 12 years were selected with each site consisting of five plots. Lengths of stems were estimated and stem diameter was measured without the shesth. Number of live leaves and stems in a clump were counted in each plant. Number of pine trees of each site was counted and soil analysis was carried out to depict the site quality.

The highesi stem lengths were recorded in the oldest site and the highest mean height recorded af er 12 years was $20 \mathrm{~m}$. Results showed that the height increases with the age and the average growth rate decreases. The highest average growth rate, $1.87 \mathrm{~m}$ per year was recorded in the 8 year old plantation and the lowest, $1.75 \mathrm{~m}$ was recorded in the 12 year old plantation. Average number of stems in a plant varies from 1 to 4 stems per plant in all four sites. Average diameter of stems i: all sites was in the range of 1.8 to $2.1 \mathrm{~cm}$, irrespective of the age of the plantation. The average number of leaves declined with the age of the plantation. In conclusion it is possible to say that although the stem length increases with the age of the plantation, the average growth rate decreases. Average stem diameter and number of stems in a plant have not shown any relationship with the age.

Proceedings of the Eighth Annual Forestry and Environment Symposium 2002 of the Department of Forestry and Environmental Science, University of Sri Jayewardenepura, Sri Lanka 